DOI: $10.1515 / \mathrm{abcsj}-2016-0005$

\title{
Female Researchers in Neo-Victorian Fiction
}

\author{
TAMMY HO LAI-MING
}

\author{
Hong Kong Baptist University
}

\begin{abstract}
Neo-Victorian novelists sometimes use postgraduate students - trainee academics - who research nineteenth-century writers as protagonists. This article discusses four neo-Victorian novels, Lloyd Jones's Mister Pip (2006), Justine Picardie's Daphne (2008), A.N. Wilson's A Jealous Ghost (2005) and Scarlett Thomas's The End of Mr Y (2006), in which female postgraduate students take the centre stage. In Victorian literature, which mirrors the gender bias in the academic world and in society at large at that time, most scholars are male. The contemporary writers' choice of female trainee academics is worth investigating as it speaks to the visibly changed gender make-up of contemporary academia. However, this utopian situation is complicated by the fact that the writers have chosen to frustrate the characters' entry into the world of scholarship by having them leave the university environment altogether before the end of the novel. The fact that these females all choose to depart the university forms a contrast with notions of the university found in Victorian novels, in which leaving or not attending university might have detrimental effects on the characters.
\end{abstract}

Keywords: Neo-Victorian fiction, literary adaptations, gender, intellectual cannibalism, trainee academics, fiction vs literary criticism, Lloyd Jones, Justine Picardie, A.N. Wilson, Scarlett Thomas

A number of novelists of neo-Victorian fiction use postgraduate students trainee academics who research nineteenth-century writers - as protagonists. It is perhaps predictable that the figure of the research student should have a recurrent role in the neo-Victorian genre, as novelists tend to cannibalise their own experience and many of them have been postgraduate students. These characters occupy a marginal or liminal position in the academic world. They are ready to enter it should they 
complete their research work with flourish but are likely to be eternally excluded from it should they fail. It is particularly interesting, then, that a number of these novels choose to complicate the characters' ambition to play a role in the world of scholarship by having them leave the university environment altogether before the end of the novel, either by their own choice or by force of circumstances. This recalls the formula of successful University novels that Janice Rossen describes: "many of the best University novels are about someone leaving academe at the end of the book" (88).

In Lloyd Jones's Mister Pip (2006), which was shortlisted for the Booker Prize and won the Commonwealth Writers' Prize, scholarly pursuit only appears in the very last pages of the novel but this brief sketch is revealing. ${ }^{1}$ Charles Dickens's Great Expectations is an important intertext of Jones's novel. A tattered copy of the canonised Victorian book is used by Mr Watts, the only white man left on the blockaded and wartorn island of Bougainville in the early 1990s, to teach Matilda, the thirteen-year-old protagonist, and her classmates. Dickens's novel provides Matilda with a glimpse of another life and "becomes her bible and her escape route" (Gribble 190). That Jones has Mr Watts announce to the class that Great Expectations is "the greatest novel" and Dickens is "the greatest writer of the nineteenth century" (18) not only betrays his admiration for the novel but also his conscious appropriation of the Victorian legacy in his own fiction. In Jones's imagination, Great Expectations is transformed from a static text to "portable property" that is a "material object, source of story, moral and imaginative stimulus, bearer of cultural capital" (Gribble 186-187). The Victorian novel is taken out of its nineteenth-century environment and becomes useful in another world, another place, for a different group of readers.

Later, after the traumatic events on the island, including the killing of Matilda's mother and Mr Watts (the latter is fed to the village pigs) and her subsequent reunion with her father in Australia and graduation from the University of Queensland, Matilda arrives in London to embark on her graduate research on Dickens. She intends to write a thesis on Dickens's orphans (199) but her research disillusions her perception of both Great Expectations and its Victorian author. In particular, it is difficult for 
Matilda to comprehend how a man who wrote so sympathetically about orphans could be so cold-hearted to his own children, exiling them emotionally and geographically one by one. She also realises that she, like many others, has been using Dickens to suit her own needs. Her research stalls, because she feels uninspired, void of "any fresh material" (215). After putting aside "that pile of paper known as my thesis" for "too long" $(215,216)$, we are told that one morning Matilda wakes up and "[takes] the top sheet of paper from 'Dickens' Orphans', turn[s] it over, and [writes], 'Everyone called him Pop Eye", (216). "Everyone called him Pop Eye" is in fact the very first sentence of Mister Pip; the novel thus circles back and in a way ends where it begins. Matilda's turning over the page of her thesis is an ingenious symbolic act: she turns her back on academic research. ${ }^{2}$

Instead of continuing her academic studies, Matilda decides to pen an autobiographical account of her life and tell her and her mother's story in Bougainville "as [it] happened" (217). With this decision, Matilda literarily turns the page on her life, transforming from a would-be scholar to a writer. However, that she chooses to write her biography on the backside of her academic work might suggest that her autobiographical reflections and the study of Dickens are somehow interdependent. But Matilda rejects both the Victorian author's fiction and her research. She dismisses Dickens's characters - "They are too loud, they are grotesques" (217) - and comes to believe that life stories provide the only authentic and meaningful narratives. For example, she finds solace in her father's unmediated reaction to her report of her mother's death: "When I told my father of my mum's death he broke down and wept. That is when I learnt there is a place for embellishment after all. But it belongs to life - not to literature" (217).

However, as readers are aware, Mister Pip is not really Matilda's autobiographical account but fiction created by Jones. That is to say, while in the narrative Matilda abandons scholarship and embraces factual reportage, what is actually rejected in the novel is scholarly endeavour; what is accepted, in the end, is fiction - fictional biography, which in a way echoes what Great Expectations is: fictional autobiography. Mister Pip, then, suggests that ultimately, Victorian cultural legacies such as 
Dickens's Great Expectations are best used to refashion new stories, address contemporary anxieties and inspire dialogues relevant to the present age, things that Mister Pip achieves by "hybridising the narratives of black and white races to create a new and resonant fable" (Laing). Although the academic setting is brief in Mister Pip, it speaks clearly against scholarly study and favours fiction as the heir to Victorian cultural heritage.

Similarly, in Justine Picardie's Daphne (2008), the PhD student Jane (she is only named once in the entire book) ${ }^{3}$ also abandons her thesis on the Brontës and Daphne du Maurier at the end of the novel. ${ }^{4}$ The reason she gives is "I don't want to try to marshal my feelings about Daphne du Maurier into a neat academic theory" (375). Jane is a cannibalistic reader: she has "devoured" all du Maurier's novels $(34,47)$ and read Heathcliff, Mr Rochester and Maxim de Winter "inside out and into myself" (38). Picardie's book alternates between the stories of Jane and du Maurier. The part on du Maurier's writing of Branwell Brontë's biography is the more interesting of the two. In this part of the book, we are also presented with du Maurier's correspondence with the scholar and former curator of the Brontë Museum, Alex Symington. Both du Maurier and Symington want to believe that Branwell was a misunderstood genius and prove that his talent was comparable, if not superior, to his sisters'.

Du Maurier's championing of Branwell is in part driven by her own desire for scholarly recognition. Although she is "the best-selling author in the country" (164), she is resentful that she is "generally dismissed with a sneer" (255) by the critics and "wants to prove herself to be a serious scholar" and "do something really worthwhile" (164). To this end, she hopes that "in proving [Branwell] to be a lost genius, she would also prove herself" (20). Here, du Maurier's opinion of herself echoes A.D. Nuttall's interpretation of the writing career of another female novelist, George Eliot: "We, looking back at George Eliot, see a major literary artist. She saw someone who had never written, would never write a great work of philosophy or history" (70). Dinah Birch likewise points to a correspondence between Eliot and "the arid scholar of Middlemarch": "But when asked to identify the original [of Casaubon], George Eliot would point to her own heart. The journals are a reminder of how 
conscious she was of the painful prospect of not living up to anticipated greatness" (22-23). Sandra M. Gilbert and Susan Gubar call this Eliot's "anxiety of authorship" (502).

The fictional du Maurier considers scholarship, then, a superior form of expression to fiction. In the end, she resignedly accepts that Branwell was not in fact a genius: "his writing talent was not equal to his sister ... Branwell turns out not to be the man I had hoped him to be" (372). Furthermore, by dedicating her biography of Branwell, The Infernal World of Branwell Brontë, to Symington, whose reputation was tarnished due to his theft of Branwell's manuscripts from several collections, du Maurier's book is also tainted. Today, du Maurier is generally remembered as the author of the novel Rebecca, which is considered to be a kind of adaptation of Brontë's Jane Eyre, while her scholarly work on Branwell is largely forgotten. This suggests that Picardie presents a triumph of the fictional response to the nineteenth century over scholarly endeavours.

$\mathrm{Du}$ Maurier's dual desire for defending Branwell and gaining recognition from the attempt is echoed in Jane, who dreams of becoming famous by "rescuing Daphne from the misunderstandings of insensitive critics that had obscured her true worth" (82). Daphne contains several layers of literary cannibalism: the contemporary student cannibalistically studies du Maurier who in turn consumes Branwell. Indeed, in the book, the language used to describe research is suggestive of cannibalism. For example, du Maurier's investigation is likened to "digging up Branwell's bones" (279) and Symington only occasionally provides her with "meagre crumbs" of Branwell to work with (301).

By incorporating Daphne du Maurier's first name as her book title (the single-word title is also an obvious nod to du Maurier's Rebecca), Picardie adopts a sense of familiarity with the famous literary predecessor. It can even be said that in her work, Picardie has authored du Maurier. Interestingly, one reviewer of Daphne comments that Picardie has "lived, breathed, eaten and drunk her heroine" (Rubin), a remark that could equally apply to the novelist's own treatment of du Maurier and Branwell. As for the figure of Symington, he is unable to complete a biography of Branwell and he realises that he is a marginal character "reduced to a 
lowly assistant to Daphne" (261). Unfortunately for him, he dies before the publication of du Maurier's The Infernal World of Branwell Brontë. With the trio of characters Jane, du Maurier and Symington, Daphne suggests a collective failure of scholarly responses to the nineteenth century. While Jane and Symington do not see their research through to completion, du Maurier manages to finish hers but is little rewarded for her effort.

Like Matilda and Jane, Sallie Declan, the heroine in A.N. Wilson's A Jealous Ghost (2005), an adaptation of Henry James's The Turn of the Screw (1898), also fails to finish her research. At the start of the book, Sallie, a lonely American doctoral student studying at University College London, "was leaving her university world, her library world" (1). We learn she is taking a break from her thesis on James, which has a strong focus on his most famous ghost story and contains an opening chapter provisionally titled "Metanym [sic] and Anonym" (51). ${ }^{5}$ During her hiatus, Sallie becomes nanny to two young children in Staverton, a remote country house in Kent and the supposed inspiration for the mansion in The Turn of the Screw. She quickly fancies herself in love with Charles Masters ("Masters," of course, is a nod to "The Master" in the original as well as to James himself), the father of her wards, Frances and Michael. The country house setting, the makeup of its occupants (two young children and a housekeeper named Gloria) and their names (Frances, Michael and Gloria are reminiscent of Flora, Miles and Mrs Grose in James's tale) not only contribute to but also strengthen Sallie's and the reader's illusion that she is reliving the experience of or communing with James's unnamed governess, who like Sallie also takes the journey from London to the country house. Sallie identifies with the governess, having an "uncanny sense that she was becoming the central figure in that story which she had been obsessively contemplating all year" (13). However, when forced to face discrepancies between reality and fiction, her already fragile mental health is aggravated. When it becomes clear that the mother of the children, Rosemary (the counterpart of Miss Jessel in the original) is not a ghost (the "jealous ghost" in the title, although at one point Sallie is herself described as "a pale ghost" [154]) but is in fact very much alive, Sallie suffers a nervous breakdown and kills Frances, mistaking her for 
the master's wife. Sallie is sent to a mental institution: "Now the room was so white. Sky white, tiles white. No colour, no blood, white as terror. You sat for eternity in this place" (185). Despite being incarcerated, she still obsesses about her thesis: "one day, she would be strong enough to stir herself and get down to writing something useful about Turn" (185). But we know it is unlikely that Sallie will resume her $\mathrm{PhD}$ research any time soon. The end of A Jealous Ghost cunningly cannibalises the first sentence of James's original, encouraging readers to further associate the story of the strayed research student with that of the Victorian governess.

Throughout A Jealous Ghost, we are given insights into Sallie's research and contemplation during her stay at the country house. This way, the author A.N. Wilson, who according to Jason Cowley is "a daring highwire scholar operating without the safety net of the academy," is able to offer explicit analysis of The Turn of the Screw, thereby collapsing the categories of fiction and scholarship and providing a self-reflexive comment on the cannibalistic relationship between neo-Victorian fiction and criticism. For example, Sallie wonders if James's story, which centres on a young governess and two children, can be read as "a paradigm of child abuse" with "paedophile men" gathering around the fireside to share "cheap thrills" (95-6). She also believes that the innocent Flora and Miles have been morally corrupted by the servants at Bly, particularly Peter Quint and Miss Jessel (96-7), an interpretation not uncommon in the scholarship on the text and in fact corroborated by James's own diary. ${ }^{6}$ But perhaps Wilson's unambiguous portrayal of Sallie as insane and physically violent, given that she is the equivalent of James's governess, is his most blatant comment on The Turn of the Screw in which the heroine's mental state and reliability are one of the text's most captivating indeterminacies. A Jealous Ghost is a hybrid, part-fiction and part-literary exegesis of the Victorian text. ${ }^{7}$

At one point, we are told that Sallie "had now read it [James's book] so often, and dwelt so much upon the rival theories and interpretations in the secondary literature, that she had begun to take for granted, hence to forget, the simple fact that it was meant ... to be 'a scare" (95). Indeed, there are so many contradictory interpretations of The Turn of the Screw in circulation that Dieter Freundlieb labels this 
phenomenon "an intellectual scandal" (79). In her early studies, Sallie is particularly influenced by poststructuralist theories such as those championed by Foucault, Todorov and Barthes (23) and she distrusts Darwinian, Marxist and biographical readings of texts (53). On one occasion she quotes Baudrillard's Simulations (1983) to argue that James wrote The Turn of the Screw in such a way that readers cannot tell whether the events recounted by the governess actually happened or were merely products of the young woman's imagination (51-2). In the article "The Haunting of Henry James: Jealous Ghosts, Affinities, and The Others" (2009), Ann Heilmann suggests that Sallie is undone by her "naïve acceptance of poststructuralism's dismissal of all truth claims": "Literary theory, in Sallie's case, literally turns into an instrument of execution" (119). Evoking Tzvetan Todorov, Stanley Fish and Roland Barthes, Sallie believes that "we make our own text" and in her version, "Rosie was dead" (170-1). This explains why Sallie intends to live out her text by killing Rosie (even if she kills Frances by mistake instead). In $A$ Jealous Ghost, then, academic pursuit is made undesirable, psychologically damaging and even deadly. The book is both a rejection and critique of the scholarly study of well-known Victorian texts and, through Sallie's experience, a morose warning against it. Ironically, when Sallie is kept in the hospital, her thesis supervisor visits her and says, "Obviously, mm, mmm, now could be a time for some more general reading around the subject" (165). The hypocrisy and cynicism in this advice, that Sallie should continue her $\mathrm{PhD}$ research during confinement, even though her supervisor is well aware that she will likely never finish it, is pungent.

In the novels discussed so far, the research students study existing Victorian texts and authors, but in The End of Mr Y (2006), Scarlett Thomas invents the Victorian writer Thomas E. Lumas for her twentyfirst-century protagonist Ariel Manto to research. ${ }^{8}$ Broadly speaking, Ariel is interested in "experiments of the minds" - her PhD supervisor suggests that she look at nineteenth-century figures such as Thomas Hardy, Alfred Tennyson and Charles Darwin as well as Einstein's theory of relativity, Edwin A. Abbot's Flatland and thought experiments such as Schrödinger's cat. However, Ariel is particularly fascinated by Lumas's 
1893 novel The End of $M r Y$ (the real-life and fictional novels share one title and their authors have the same name "Thomas"), a supposedly cursed book which causes its author and all its readers to die. Allegedly and enigmatically, there is only one copy of this book in the world, which is kept in a German bank vault. Lumas's The End of Mr Y follows Mr Y's discovery of a curious tincture that allows him to journey across time and space by occupying the consciousness of other living beings. In the end, he chooses this alternative mind world, called "Troposphere," over the real one and in effect voluntarily commits physical suicide, hence the "end" in the title.

At intervals throughout her novel, Thomas includes sections from the ostensibly nineteen-century text, which are written by Thomas but signed Lumas. This, and the fact that both Thomas and Lumas write a book with the same title, suggests a communion between the contemporary author and her nineteenth-century invented counterpart, a communion which also mirrors the entire novel as it contains both contemporary and Victorian styles in one body. Despite the fact that employing real-life personae in neo-Victorian fiction is a convention of the genre and lends authenticity to texts, Thomas does not use a historical figure but instead creates her own Victorian celebrity. This is perhaps because Lumas is not one person but is, according to Ann Heilmann and Mark Llewellyn, possibly a composite of several Victorian models: Edwin A. Abbott, author of Flatland (1884), the mathematician and poet James Clerk Maxwell and Samuel Butler, whose Erewhon (1872) and NoteBooks are referred to in the novel a number of times (191-192). This move allows Thomas to commune with not one but several male Victorian figures. However, that Samuel Butler may be the main source for Lumas is hinted at through a pair of suggestive names in the text. "Lumas" is almost a palindrome of "Samuel," just as Butler's Erewhon is almost a palindrome of "Nowhere" (a theme present throughout the book, especially the Troposphere into which both Mr Y and Ariel disappear). The name "Lumas", then, more powerfully recalls Butler (or the title of his famous work) than the other Victorian writers. Via the invented name "Thomas E. Lumas," the contemporary author (Scarlett Thomas) communes with the Victorian critic and novelist (Samuel Butler). ${ }^{9}$ 
While the fiction-within-the-fiction version of The End of $\mathrm{Mr} Y$ charts its eponymous character's exploration and final disappearance into the other world, Thomas's The End of Mr Y is itself a thought experiment novel which contemplates postmodernist, poststructuralist and semiotic ideas of illusion and reality, sometimes through the lenses of and works by Victorian philosophers and writers, including the fictional Lumas. Because the protagonist of her novel is a $\mathrm{PhD}$ student researching "experiments of the minds," Thomas has many opportunities to discuss different theories and literary works about the boundaries of reality. Jean Baudrillard, Martin Heidegger and Jacques Derrida, among others, are referred to in the text. Ariel, however, prefers Victorian thought: "The nineteenth-century crowd were wrong, on the whole, but we're somehow doing worse than that. We're now living with the uncertainty principle and the incompleteness theorem and philosophers who say that the world has become a simulacrum - a copy without an original" (44). Here, as in Wilson's A Jealous Ghost, there is an ambivalence towards contemporary philosophical and literary ideas. A similar scepticism can also be found in D.M. Thomas's Charlotte: The Final Journey of Jane Eyre, in which "contemporary scholarship in general and women's studies in particular are derided" (Gutleben 182), as well as in Graham Swift's Ever After, where academics' "lengthy critical discussions" and "erudite commentaries" (70) are dismissed by the main protagonist. Neo-Victorian novels featuring academic characters, then, seem to repudiate and undermine contemporary scholarly methods and to some extent retreat into the certainties and solaces of the Victorian world.

Ariel delights that her reading of The End of $M r Y$ is untainted by a plethora of adaptations (because the book is scarce): "It's a strange experience, coming to such an old book without the benefit of a thousand TV adaptations and study guides and reading groups" (55). This is both a comment on contemporary treatment of canonical Victorian texts and a reflection of Thomas's own choice of creating a new Victorian writer rather than appropriating known ones: her book is not marred by preexisting interpretations. In the context of the current discussion, what is particularly interesting is Ariel's response to Lumas's The End of $\mathrm{Mr} Y$ and her research progress. Predictably, she cannot resist reading the book 
despite its curse and she follows Mr Y's and Lumas's example to create the potion and journey into the Troposphere. She thus metaphorically drinks the Victorian past and becomes in some sense a neo-Victorian adaptation of Lumas's The End of $M r Y$ by repeating the pattern of the fictional Victorian author and his character.

In the end, Ariel, accompanied by her lover Adam, a former priest and a theology lecturer, enters Lumas's mind and makes him destroy the manuscript of The End of $\mathrm{Mr} \mathrm{Y}$ - the secret embedded in the book would be too dangerous for mankind if it fell into evil hands. In this moment, Ariel communes with her research subject and Victorian precursor, albeit briefly, and at the same time destroys his powerful and haunting text. Put another way, she communes with the Victorian past in order to annihilate it. This perhaps provides the ultimate example of the neo-Victorian's aggressive ambivalence towards the past. After the mission is complete, Ariel decides not to depart the Troposphere: "I can't get what I want outside of here. ... I want the knowledge I can find in here. I want to know how it all started, and what consciousness is" (500). By leaving behind the contemporary physical world to travel forever with Adam in the alternate universe, feeding on mind after mind, Ariel has abandoned her earthly PhD studies, which do not satisfy her desire for first-hand knowledge. Their decision to drink the potion together and search for knowledge provides an obvious echo of the story of Adam and Eve, a reference which is literally manifested in the Epilogue. By choosing to live in the Troposphere, Ariel undertakes the ultimate form of intellectual cannibalism by living exclusively off the minds of others. This coincides with Suzanne Keen's characterisation of successful knowledge-seekers: "An academic outsider makes a better truth-finder than a 'qualified' researcher" (30). Ariel's decision is also in one crucial sense very similar to Matilda's in Mister Pip: both heroines reject scholarship, in particular, Victorian scholarship, for a different path. While one goes back to her original world (Matilda), the other goes to an unknown but seemingly infinite one (Ariel).

The neo-Victorian writers discussed in this article all have their heroines leave the world of scholarship, pointing to the writers' general mistrust of contemporary academic pursuits and their critique of modern 
academia. The student characters all abandon their research - they are unwilling or unable to continue or they find scholarship unfulfilling. Because of their very form (they are fiction, not scholarship), these novels also seem implicitly to endorse fiction, rather than academic research, as a preferred means to inherit the Victorian legacy.

In Victorian literature, most scholars are male, which mirrors the gender bias in the academic world and in society in general at that time. The female trainee academics in the neo-Victorian novels discussed here, then, speak to the changed gender make-up of contemporary academia. The fact that these women all choose to depart the university also forms a contrast with notions of the university found in Victorian novels, in which leaving the university - or never being allowed to enter it - can destroy a life. In Thomas Hardy's Jude the Obscure (1895), for example, Jude is denied entry to the colleges, which "[held] back the spread of adult education to the working class" in order to protect "the over-crowded professions" (Ingham xiii). This experience negatively impacts his life and worldview. In the contemporary novels, however, the beginning scholars willingly give up their academic pursuits, an act which could be read as both a slightly retrograde view of women's academic aptitude and perseverance and a form of female empowerment and liberation.

\section{Notes:}

${ }^{1}$ Lloyd Jones has an unusual relationship with academia. He did not graduate from Victoria University because he refused to pay outstanding library fines but was later given an honorary doctorate by the same institution. On "The Book Show" broadcast by Australia's RadioNational, host Ramona Koval pointed out that it was through his fiction that Jones "finally got academic recognition" (Koval and Jones 2009).

${ }^{2}$ Apart from abandoning her graduate research, Matilda also turns her back on London, one of the centres of world education. At the end, she chooses to go home, presumably the island of Bougainville: "I had decided to leave England" (217) and "I would try where Pip had failed. I would try to return home" (219).

${ }^{3}$ The name 'Jane' recalls the ur-text Jane Eyre, which is the model for Rebecca and to some extent Daphne. In Daphne, Jane is married to a husband emotionally haunted by his first wife - resembling a version of the Rochester-Jane-Bertha relationship. 
4 Jane's original idea for her thesis is "the Brontës' imaginary worlds of childhood, with particular reference to Branwell's influence on Emily and Charlotte" but she also attempts to incorporate du Maurier in the thesis because it is through du Maurier's biography The Infernal World of Branwell Brontë (1972) that she has become interested in Branwell. Note that both Matilda in Mister Pip and Jane in Daphne are initially interested in researching aspects of Victorian childhood (Matilda on Dickens's orphans and Jane on 'the Brontës' imaginary worlds of childhood"). The heroines' fixation with childhood hints at their ultimate failure to enter the adult world of scholarship.

5 Coincidentally, Alan Hollinghurst's Booker Prize-winning The Line of Beauty (2004) also has a main character who like Sallie is writing a PhD thesis on Henry James at University College London. Nick Guest, Hollinghurst's protagonist, begins his dissertation on James's style but his research is not the main focus of the novel nor is it much discussed. As Cora Kaplan writes, "[H]e gets distracted from it in his pursuit of pleasure, in his case gay, interracial, cross-class sex" (74). That Nick sidelines his academic study in favour of a Jamesian exploration of lifestyle is perhaps the novelist's comment on the ineffectuality of scholarship to truly understand a Victorian writer's aesthetics.

6 "For at least a century conventional wisdom had held that servants were corrupters of children" (Schrero 262).

${ }^{7}$ Charles Palliser's neo-Victorian novel, The Quincunx (1989), similarly appropriates literary exegesis. According to Palliser, his intention in the book was not to passively imitate Victorian novels but to recontextualise them, and "to offer a critique like an academic work, but in the form of another novel" (qtd. in Coe 21).

${ }^{8}$ Scarlett Thomas currently teaches creative writing at the University of Kent.

Her first three novels feature an English literature lecturer.

9 The use of invented Victorian celebrities as stand-ins for historical figures is also seen in A.S. Byatt's Possession (1990), in which the fictional Victorian poet Randolph Henry Ash is "a composite portrait of Matthew Arnold, Tennyson, George Eliot's husband G.H. Lewes and, most importantly, Robert Browning" and Christabel LaMotte and her work "are inspired by nineteenth-century poets such as Emily Dickinson, Charlotte Brontë, Christina Rossetti and Elisabeth Barrett Browning" as well as "the British suffragette Christabel Pankhurst and the heroine of Coleridge's unfinished poem "Christabel"' (Franken 87, 88). We also recall the use of Alfred and Dorothea Gibson in Gaynor Arnold's Girl in a Blue Dress (2008) to represent Charles and Catherine Dickens. By creating new monikers for the Victorian celebrities, the novelists may feel that they have more latitude in fictionalising aspects of their lives. 


\section{Works Cited}

Birch, Dinah. "No Wonder It Ached." London Review of Books 22.10 (13 May 2009): 22-33. Print.

Coe, Jonathan. "Shuddering Organisms." London Review of Books 16.9 (1994): 21. Print.

Cowley, Jason. "Another Screw on the Loose.” Observer. 10 Apr. 2005. Web. 12 Feb. 2016.

Franken, Christien. A.S. Byatt: Art, Authorship, Creativity. Basingstoke, Hampshire; New York, N.Y.: Palgrave, 2001. Print.

Freundlieb, Dieter. "Explaining Interpretation: The Case of Henry James's The Turn of the Screw." Poetics Today 5.1 (1984): 79-95. Print.

Gilbert, Sandra M. and Susan Gubar. The Madwoman in the Attic: the Woman Writer and the Nineteenth-Century Literary Imagination. New Haven and London: Yale University Press, (1979) 2000. Print.

Gribble, Jennifer. "Portable Property: Postcolonial Appropriations of Great Expectations." Victorian Turns, NeoVictorian Returns: Essays on Fiction and Culture. Ed. Peter Gay, Judith Johnston and Catherine Waters. Newcastle upon Tyne: Cambridge Scholars, 2008. 182-192. Print.

Gutleben, Christian. Nostalgic Postmodernism: The Victorian Tradition and the Contemporary British Novel. Amsterdam \& New York: Rodopi, 2001. Print.

Heilmann, Ann. "The Haunting of Henry James: Jealous Ghosts, Affinities, and The Others." Haunting and Spectrality in Neo-Victorian Fiction: Possessing the Past. Ed. Rosario Arias and Patricia Pulham. Basingstoke: Palgrave Macmillan, 2009. 111-130. Print.

Heilmann, Ann and Mark Llewellyn. Neo-Victorianism: the Victorians in the Twenty-first Century, 1999-2009. Basingstoke: Palgrave Macmillan, 2010. Print.

Ingham, Patricia. "Introduction." Jude the Obscure. Ed. Patricia Ingham. Oxford: Oxford University Press, 2002. Print.

Jones, Lloyd. Mister Pip. London: John Murray, 2008. Print.

Kaplan, Cora. Victoriana: Histories, Fictions, Criticism. Edinburgh: University of Edinburgh Press, 2007. Print.

Keen, Suzanne. Romances of the Archive in Contemporary British Fiction. Toronto; Buffalo: University of Toronto Press, 2001. Print.

Koval, Romana and Lloyd Jones. "Lloyd Jones and The Man in the Shed." RadioNational. 15 Sept. 2009. Web. 12 Feb. 2016.

Laing, Olivia. "Pip Pip." Guardian 7 July 2007. Web. 12 Feb. 2016.

Nuttall, A.D. Dead from the Waist Down: Scholars and Scholarship in Literature and the Popular Imagination. New Haven, Conn. and London: Yale University Press, 2003. Print.

Picardie, Justine. Daphne. London: Bloomsbury, 2009. Print.

Rossen, Janice. The University in Modern Fiction: When Power Is Academic. New York, N.Y.: St. Martin's Press, 1993. Print.

Rubin, Martin. "Du Maurier Is Alive in this Tale." Los Angeles Times. 8 Aug. 
2008. Web. 12 Feb. 2016.

Schrero, Elliot M. "Exposure in The Turn of the Screw." Modern Philology 78.2 (1981): 261-274. Print.

Showalter, Elaine. Faculty Towers: The Academic Novel and Its Discontents. Philadelphia: University of Pennsylvania Press, 2005. Print.

Thomas, Scarlett. The End of Mr Y. Edinburgh: Canongate, 2008. Print.

Wilson, A.N. A Jealous Ghost. London: Arrow Books, 2006. Print. 